\title{
ヘッド・マウント・ディスプレイにおける 立体像の眼調節機能への影響
}

\author{
○岩崎常人（産業医科大学眼科） \\ 河合隆史、柴田隆史、野呂影勇 (早稲田大学人間科学部) \\ 井上哲理（神奈川工科大学）

\begin{abstract}
Effect of stereoscopic images using the head mounted display on ocular accommodation IWASAKI Tsuneto (Univ. of Occupational and Environmental Health, Japan)

KAWAI Takashi, SHIBATA Takashi, NORO Kageyu (Waseda Univ.)

INOUE Tetsuri (Kanagawa Institute of Technology)
\end{abstract}

\section{1. 目的}

ヘッド•マウント•ディスプレイ (head mounted display；以下 HMD）は、バーチャル・リアリ ティシステムにおける視覚情報呈示装置と して用いられたり、大画面で映像を鑑賞す る事が出来る個人用テレビとしての利用 が可能である。しかし、眼前に装着するた めに視野が限定されたり、人為的に両眼視 差を用いて立体視を誘起するために、映像 鑑賞時において自然視での視機能のあり 方とは様相を異にする。そのために HMD を用いて映像を鑑賞する事によって、鑑賞 者は眼疲労や種々の不定愁訴をもつ。

そこで、HMD による立体像の負荷が、 調節機能へ及ほす影響を視差量の違いに おいて実験的に検討した。

\section{2. 方法}

20 歳から 24 歳までの女子 8 例を対象に 実験を行った。HMD の脱着による調節機 能への影響を排除するために、立体像呈示 装置には、HMD 内に使用されている光学 系と同様の光学ユニットを実験台上に設 置し使用した。0.7 inch の液晶画面を両眼 前に置き、画面と眼球との間にレンズ系を 付加する事で、眼球から $3 \mathrm{~m}$ 前方に両画面
の映像が融像される様にした。これによっ て 0.7 inch の画面は、理論的に 97 inch（水 平視角 $37^{\circ}$ ) の虚像として認識される画面

（虚像画面）となった。

この光学ユニット上で被験者に注視さ せた立体像は、水平・垂直視角を $2^{\circ}$ とす る立方体の輪郭図であった。この輪郭図を 赤、緑、青色と無作為に変化させ、被験者 は指定された色の立方体が呈示される毎 にキーボード上のボタンを押した。以上を 作業課題とする負荷は、被験者を顎台に固 定した状態で 15 分間与えられた。

立体像としての再生位置、つまり認識さ れると考えられる理論的位置は、画面上の 左右像のずれ量を変化させる事により制 御した。立体像の呈示条件は、立方体の中 心位置と虚像画面位置との間の両眼視差 を(1)画面前方に $1.0^{\circ}$ と(2)画面上 $0^{\circ}$ 、(3)画 面後方 $0.5^{\circ}$ 及び(4)画面後方 $1.0^{\circ}$ とする 4 種類であった。

各条件間での調節機能への影響の比較 は、それぞれの負荷の前後に赤外線オプト メーターを用いて調節ステップ応答を測 定し、得られた波形から調節時間を解析し た。遠方視から近方視をした場合に調節応 答が終了するまでの時間を調節緊張時間 
とし、近方視から遠方視に要した時間を調 節弛緩時間とした。

\section{3. 結果}

虚像画面前方で視差を $1.0^{\circ}$ として立体 像を認識させた場合、負荷前後における平 均調節緊張時間（図 1）と平均調節弛緩時 間（図 2）は、それぞれ $0.94 \pm 0.22$ 秒から $1.20 \pm 0.26$ 秒と、 $0.86 \pm 0.10$ 秒から $1.19 \pm$ 0.33 秒へと有意に延長した(ともに $\mathrm{P}<0.05$ 、 t-test による)。しかしその他の呈示条件に おいては、調節緊張時間と調節弛緩時間に
有意な差は認められなかった。

\section{4. 結論}

HMD における立体像の負荷は、両眼視 差を交差側として HMD の虚像画面前方で 与えられる場合に調節機能への影響が大 である。逆に、今回の実験の様に視差 $1^{\circ}$ 以内であれば、視差を同側として虚像画面 の後方に立体像を認識させると、調節機能 への影響が少ないと考えられる。

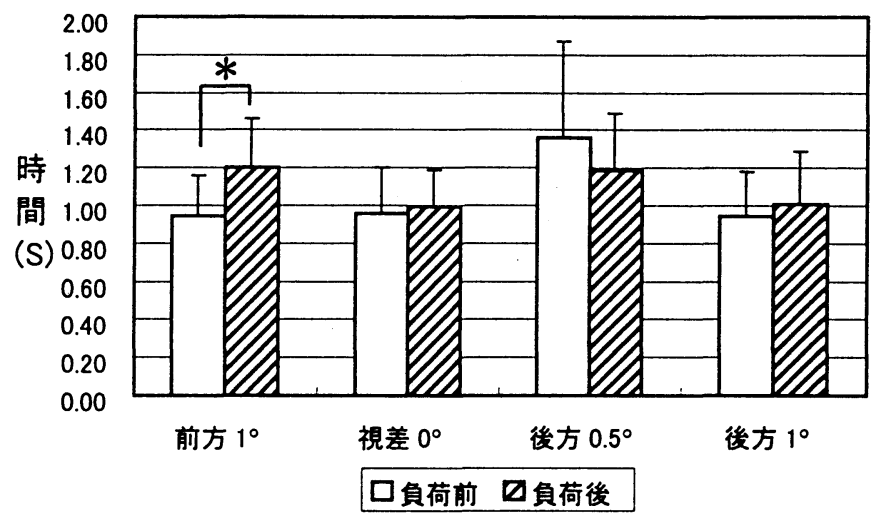

図 1 立体像負荷前後における調節緊張時間の変化

前方 $1^{\circ}$ : 視差を交差 $1^{\circ}$ としてHMDの虚像画面より前方に立体像を再生 視差 $0^{\circ}:$ : 視差を $0^{\circ}$ として虚像画面上に再生 後方 $0.5^{\circ}$ : 視差を同側 $0.5^{\circ}$ としてHMDの虚像画面より後方に立体像を再生 後方 $1^{\circ}$ : 視差を同側 $1^{\circ}$ としてHMDの虚像画面より後方に立体像を再生

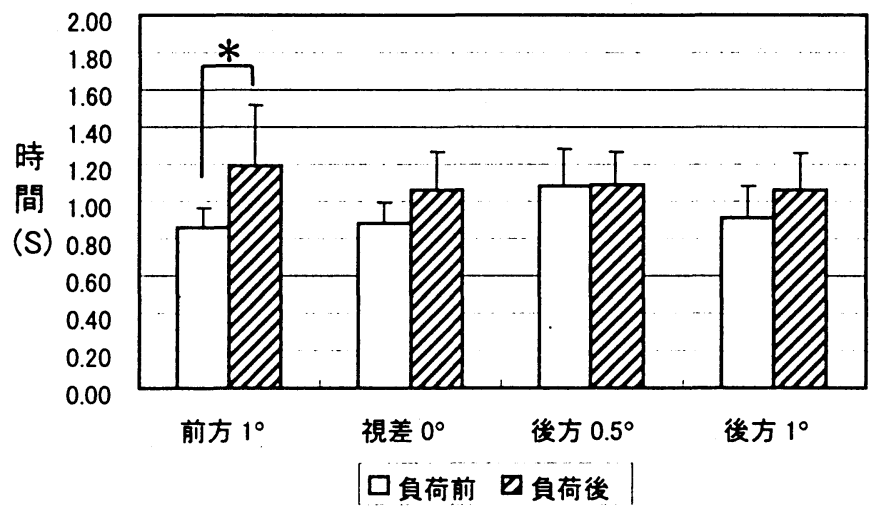

図 2 立体像負荷前後における調節驰緩時間の変化 前方 $1^{\circ}$ 、視差 $0^{\circ}$ 、後方 $0.5^{\circ}$ 後方 $1^{\circ}$ : 図 1 と同様 